\title{
Prevalence of Hepatitis C in General Population of District Swat, Khyber Pakhtoonkhwa, Pakistan
}

\section{Ajmal Khan*}

Alazhar Public School and College Madyan Swat, Bahrain, Pakistan

*Corresponding author: Ajmal Khan, Alazhar Public School, and College Madyan Swat, Bahrain, Pakistan, Tel: 923449609199; E-mail: ajmalswat94@gmail.com Received date: October 11, 2018; Accepted date: November 20, 2018; Published date: November 26, 2018

Copyright: (c) 2018 Khan A. This is an open-access article distributed under the terms of the Creative Commons Attribution License; which permits unrestricted use; distribution; and reproduction in any medium; provided the original author and source are credited.

\begin{abstract}
The present study was conducted on the prevalence of Hepatitis C in the general population of District Swat, Khyber Pakhtunkhwa province, Pakistan from January 2017 to October 2017. A total of about 1415 individuals were examined, among which $74(5.22 \%)$ were found positive against HCV antibody test. Of the 1415 examined individuals, $759(53.6 \%)$ were males and 656 (46.4\%) were females. Among the $74(5.22 \%)$ infected individuals, 32 were females and 42 were males. A maximum number of individuals who were HCV antibody positive belongs to the age group the between 36 to 55 years (21 and 17 i.e. $7 \%$ and $6.9 \%$ ). samples found positive for antibody and antigen-based test, were further investigated for the presence of Hepatitis $C$ related RNA with PCR and the results show that only $32(2.3 \%)$ individuals have Hepatitis C viral RNA. This is about $(43.24 \%)$ of the total HCV antibody positive individuals. Out of 32 HCV-PCR positive samples, 11 (34.4\%) were symptomatic and 21 (65.6\%) were asymptomatic. Further analysis of the PCR positive samples shows that $20(62.5 \%)$ were females and $12(37.7 \%)$ were male. Among the HCV positive samples, genotype 3a was the most abundant $18(56.2 \%)$ of the infected individuals followed by genotype $3 \mathrm{~b}$ in 4 female (20\%) and 3 male (25\%), genotype $2 \mathrm{a}$ in 3 females (15\%) and 2 male $(16.6 \%)$, and $1 \mathrm{~b}$ in $1(5 \%)$ females and $1(8.3 \%)$ male. No unknown RNA sequences were found in the studied samples.
\end{abstract}

\section{Keywords: Hepatitis C; HCV; PCR; Pakistan}

\section{Introduction}

Hepatitis C occurs due to Hepatitis C virus this disease may be mild or severe. A mild type of Hepatitis $\mathrm{C}$ is normally short-term illness but with the passage time, it becomes a chronic infection if left untreated. Chronic Hepatitis $\mathrm{C}$ is a severe type of liver disorder leading to hepatocellular carcinoma, cirrhosis and even to death. Hepatitis $\mathrm{C}$ and hepatocellular carcinoma are the worldwide health issues [1]. Hepatitis $\mathrm{C}$ normally remains non-symptomatic but in severe cases, may cause liver cirrhosis. Hepatitis $\mathrm{C}$ virus is one among the most precarious disease in humans with markable clinical indications throughout the world. After Hepatitis B, the second most fatal viral disease is HCV [2]. HCV viral infection of the liver is associated with greater mortality $[3,4]$. Because hepatocellular carcinoma and liver cirrhosis are more common among anti-HCV positive patients [4]. Hepatitis C virus (HCV) is body fluid-borne hepatotropic viruses and is the chief source of long-lasting liver diseases, cirrhosis and death [5]. The possibility of Hepatitis transmission through blood and other body fluids are known since long time ago [6,7]. The first time Hepatitis $C$ virus was cloned in 1989 [8]. Hepatitis C virus (HCV) is a solo stranded positive-sense RNA enveloped virus that includes in family Flaviviridae and genus Hepacivirus [9]. There are more than ten well-known genotypes of HCV out of these; the most important are six genotypes. Each of these six contains a small genome of about 9600 nucleotides that are usually being tested in different clinical laboratories throughout the world. All of these genotypes having different subtypes $[10,11]$. The several genotypes and their subtypes do not have any big difference in their pathogenicity or virulence. But these variations among a single pathogen have much medical and clinical importance. The divers and highly mutable structure of HCV is also an important factor that leads to complications in the production of a vaccine against this virus [9].

In addition, these various genotypes are linked to various aspects of $\mathrm{HCV}$ infections that include the observation of a clinical aspect of persistent HCV infection and its epidemiology. This causes Hepatitis C, which is one of the most fatal viral diseases caused by a virus [9]. Pakistan is among one of those countries which are severely affected by Hepatitis C virus. The occurrence of Hepatitis C virus in Pakistan is higher than other states of the region like India, Nepal, Myanmar, Iran and Afghanistan [12]. In Pakistan mostly the patient of viral infections are brought to the hospitals when they are at the late stages of liver damage. The late diagnosis increases the threats of liver failure and decreases the effect of antiviral therapies [13-15]. Afghan migrants in Balochistan acquired a higher proportion of Hepatitis B and C than Pakistanis. Low literacy, deprived socioeconomic status, and poor sanitized environments could be involved in such a higher prevalence rate of HCV [16,17]. In Pakistan, Hepatitis B surface antigen (HBsAg) and anti-Hepatitis $\mathrm{C}$ virus (HCV) are positively detected correspondingly in $2.5 \%$ and $4.8 \%$ of the population, presenting a total of about $7.6 \%$ Hepatitis occurrence in the normal population. The recognized high burden of prolonged liver sickness is due to the high HCV occurrence rate [18]. An adequate number of Pakistan population is unaware of the epidemiology, threat factors, and severity of Viral Hepatitis. Although the screening and diagnostic recommendations advocate early detection of HCV [14].

From an assessment by the World Health Organization (WHO), Hepatitis $\mathrm{C}(\mathrm{HCV})$ is infecting almost $3 \%$ population of the world. Worldwide 1.70 billion individuals are septic by Hepatitis $C$ virus so far and $0.3-0.4$ billion people adding to the list with each passing year $[1,3,19]$. According to the World Health Organization (WHO), the occurrence of HCV in Pakistan is ranging $3-13 \%$ in different areas 
Page 2 of 3

[20]. A countrywide assessment done by Pakistan Medical Research Council (PMRC) from July 2007 to May 2008 shows that occurrence of Hepatitis C is $5 \%$, in the general population of Pakistan (PMRC, 2007-2009). The intra-province occurrence of Hepatitis $C$ was extremely high in Punjab (6.7\%) followed by Sindh (5.0\%), Balochistan (1.5\%) and Khyber Pakhtoonkhwa (1.1\%) [21].

\section{Aims and Objectives}

To investigate Hepatitis $\mathrm{C}$ virus infection in individuals of both sexes of swat.

\section{Method and Materials}

\section{Study area}

The present survey was conduct to examine the frequency of Hepatitis C virus infections in people of district Swat, which is located in Malakand Division, between $72^{\circ} \mathrm{E}$ to $74^{\circ} \mathrm{E}$ longitude and $34.40^{\circ} \mathrm{N}$ to $35.40^{\circ} \mathrm{N}$ latitude and is a portion of the Provincially Administrated Tribal Area (PATA) of Khyber Pakhtunkhwa region of Pakistan. Swat having an area of about 5337 square kilometers. The terms found in older sources for Swat are Udyana due to the beauty of the valley and Suvastu the name of the river.

\section{Methodology}

Hepatitis-C prevailing survey was conducted among the apparently healthy male and female population of district swat. The blood samples of all the individuals were collected by an authorized technician in the laboratory and were a screen for Anti HCV using immunechromatography (ICT method. Those who were positive by ICT were further tested by Enzyme-Linked Immunosorbent Assay (ELISA). The individuals appearing positive in the screening were further subjected to PCR based detection of viral DNA/RNA and its correlation with different diseases and risk factors were also studied and then analyzed through PCR for genotype detection. The obtained data analyzed by SPSS version 16 software were used to measure the frequency of the $\mathrm{CHV}$ virus.

\section{Results}

A total of 1415 cases were studied which include 759 (53.6\%) males and $656(46.4 \%)$ females with age group between 1 to 66 years or older (Table 1).

\begin{tabular}{|l|l|l|l|l|l|l|l|}
\hline $\begin{array}{l}\text { Age } \\
\text { group } \\
\text { s }\end{array}$ & $\begin{array}{l}\text { Individu } \\
\text { al } \\
\text { examine }\end{array}$ & $\begin{array}{l}\text { male } \\
\text { s }\end{array}$ & $\begin{array}{l}\text { femal } \\
\text { es }\end{array}$ & $\begin{array}{l}\text { Anti-HCV } \\
\text { positive } \\
\text { individual } \\
\text { s }\end{array}$ & $\begin{array}{l}\text { HCV } \\
\text { PCR } \\
\text { positi } \\
\text { ve }\end{array}$ & $\begin{array}{l}\text { Anti-HCV } \\
\text { positive } \\
\text { individuals } \\
\%\end{array}$ & $\begin{array}{l}\text { HCV } \\
\text { PCR } \\
\text { (\%) }\end{array}$ \\
\hline $1-15$ & 121 & 72 & 49 & 3 & 0 & 2.47 & 0 \\
\hline $16-25$ & 232 & 134 & 98 & 7 & 2 & 3.01 & 0.86 \\
\hline $26-35$ & 274 & 143 & 131 & 12 & 6 & 4.37 & 2.19 \\
\hline $36-45$ & 300 & 159 & 141 & 21 & 10 & 7 & 3.33 \\
\hline $46-55$ & 246 & 134 & 112 & 17 & 9 & 6.91 & 3.65 \\
\hline $56-65$ & 160 & 88 & 72 & 10 & 4 & 6.35 & 2.5 \\
\hline
\end{tabular}

\begin{tabular}{|l|l|l|l|l|l|l|l|}
\hline $\begin{array}{l}66 \text { or } \\
\text { older }\end{array}$ & 82 & 29 & 53 & 4 & 1 & 4.8 & 1.2 \\
\hline Total & 1415 & 759 & 656 & 74 & 32 & 5.22 & 2.26 \\
\hline
\end{tabular}

Table 1: Details of cases involved in the study.

\section{Anti-HCV positive cases}

Out of 1415 individuals, 74 (5.22\%) were found positive against HCV antibody test. Among which 32 were females and 42 were males. A maximum number of individuals who were HCV antibody positive belongs to age groups between 36 to 55 years ( 21 and 17 i.e $7 \%$ and $6.9 \%)$.

\section{$\mathrm{HCV}$ genotypes}

The samples found positive for antibody and antigen-based screening, were further investigated for the presence of Hepatitis $\mathrm{C}$ related RNA with PCR and results show that only $32(2.3 \%)$ individuals having Hepatitis C viral RNA. Which is about (43.24\%) of the total HCV antibody positive individuals Table 1 . Out of $32 \mathrm{HCV}$ PCR positive samples, 11 (34.4\%) were symptomatic and 21 (65.6\%) were asymptomatic, $20(62.5 \%)$ of the PCR positive samples were females and $12(37.7 \%)$ were male. Among the HCV positive samples, genotype $3 \mathrm{a}$ was the most dominant found in 18 (56.2\%) of the total PCR positive individuals. In which $12(60 \%)$ were PCR positive females and $6(50 \%)$ were PCR positive male subjects. The other genotypes detected in the population included $3 \mathrm{~b}$ in 4 female $(20 \%)$ and 3 male (25\%), 2a was found in 3 females (15\%) and in 2 male (16.6\%), and $1 \mathrm{~b}$ was found in $1(5 \%)$ females and one (8.3\%) male. None of the unknown RNA sequences was found as that was noted in other regions of the country.

\section{Discussion and Conclusion}

Liver diseases are increasing day by day in developing countries including Pakistan. Hepatitis $\mathrm{C}$ is also one of the chronic liver disease caused by the Hepatitis $\mathrm{C}$ virus. In Pakistan, the prevalence of Hepatitis C is nearly $80 \%$ in patients with liver diseases. Hepatitis c prevalence is high in the general population [22]. Studies in recent eras showed that about $6 \%$ of the Pakistani population is infected by HCV [23].

A detailed study of our results shows that the maximum number of people infected with HCV fall in the age groups between 26 to 55 years in district Swat. These results show similarities to the study of Ali et al. [24], Shah et al. [11] on the prevalence HCV. But also disagrees to the study that records high HCV occurrence among the younger or older age groups [25].

In the present study, the PCR results show that the prevalence of $\mathrm{HCV}$ is $(2.3 \%)$ that is very less as compared to other parts of the country. The HCV Genotyping for all the 32 samples that were found positive by qualitative PCR shows that genotype $3 \mathrm{a}$ is the most abundant among the infected individuals followed by genotype $3 \mathrm{~b}$ and then 2a. These results show similarities to the previously done studies on Pakistani population about the same issue [26-28]. 


\section{References}

1. Ghulam, F, Shehla S, Anam R, Suresh KM, Saeed Q et al. (2015) Hepatitis C status in Karachi, Pakistan, a five-year survey at Civil Hospital Karachi, Pakistan. Int J Clin Medi 6: 797-804.

2. Leiveven J (2004) Pegasys/RBV improves fibrosis in responders, relapsers nonresponders with advanced fibrosis. 55th Annual Meeting of the American Association for the Study of Liver Disease: 2004 October 29November 2: Boston, MA, USA.

3. Fabrizi F, Takkouche B, Lunghi G, Dixit V, Messa P, et al. (2007) The impact of Hepatitis $\mathrm{C}$ virus infection on survival in dialysis patients: A meta-analysis of observational studies. J. Viral. Hepat 14: 697-703.

4. Henderson WA, Shankar R, Gill JM, Kim KH, Ghany MG, et al. (2010) Hepatitis C progressing to hepatocellular carcinoma: the HCV dialysis patient in dilemma. J Viral Hepat 17: 59-64.

5. Baig S, Siddiqui AA, Ahmed WU, Qureshi H, Arif A (2009) Frequency of Hepatitis C and D superinfection in patients with Hepatitis B related complex liver disorders. J Coll Physicians Surg Pak 19: 699-703.

6. Mahoney FJ (1999) Update on diagnosis, management, and prevention of Hepatitis B virus infection. Clin Microbiol Rev 12: 351-366.

7. Hillyer CD, Hillyer KL, Strobe FJ, Jeffries LC, Siberstein LE (2001) Handbook of transfusion medicine. Academic Press, London.

8. Kuo G, Choo Q, Alter H, Gitnick G, Redeker A, et al. (1989) An assay for circulating antibodies to a major etiologic virus of human Non-A, Non-B Hepatitis. Science 21: 362-364.

9. Shah HN, Shabbir G (2002) A review of published literature on Hepatitis B and C Virus prevalence in Pakistan. J Coll Phys Surg Pak 12: 368-371.

10. Zein NN, Persing DH (1996) Hepatitis C Genotypes: current trends and future implications. Mayo Clin Proc 71: 458-462.

11. Shah FU, Salih M, Malik IA, Hussain I (2002) Increasing prevalence of chronic Hepatitis and associated risk factors. Pak J Med Res 41: 46-50.

12. Hutin Y, Kitler M, Dore GJ, Perz J, Armstrong G, et al. (2004) Global burden of disease (GBD) for Hepatitis C. J Clin Pharmacol 44: 20-29.

13. Strader DB, Wright $T$, Thomas DL, Seeff LB (2004) Diagnosis, management, and treatment of Hepatitis C. Hepatol 39: 1147-1171.

14. Lok AS, Mcmahon BJ (2007) Chronic Hepatitis B. Hepatol 45: 507-539.

15. DI-Bisceglie AM (2009) Hepatitis B and hepatocellular carcinoma. Hepatol 49: S56-S60.
16. AhmadJ, Taj AS (2004) Frequency of Hepatitis B and Hepatitis C in healthy blood donors of NWFP. J PGMI18: 343-352.

17. Quddus A, Stephen P (2005) Prevalence of Hepatitis B among Afghan refugees living in Balochistan, Pakistan. Int J Infec Diseases 4: 01-07.

18. Qureshi H, Bile KM, Jooma R, Alam SE, Afridi HU (2010) Prevalence of Hepatitis $\mathrm{B}$ and $\mathrm{C}$ viral infections in Pakistan: Findings of a national survey appealing for effective prevention and control measures. East Mediterr Health J 16: 15- 23.

19. Butt AA, Skanderson M, Mcginnis KA, Ahuja T, Bryce CL, et al. (2007) Impact of Hepatitis $C$ virus infection and other comorbidities on survival in patients on dialysis. J Viral Hepat 14: 688-696.

20. Jadoon SMK, Jadoon S, Muhammad I (2010) Response to standard interferon a2b and ribavirin combination therapy in chronic Hepatitis $\mathrm{C}$ treatment naïve patients. J Ayub Med Coll Abbottabad 22: 164-166.

21. Choudhary IA, Khan SA, Samiullah (2005) Should we do Hepatitis -B and $\mathrm{C}$ screening on each patient before surgery. Pak J Med Sci 21: $278-280$.

22. Lauer GM, Walker BD (2001) Hepatitis C virus infection. N Engl J Med 345: 41-52.

23. Raja NS, Janjua KA (2008) Epidemiology of Hepatitis C virus infection in Pakistan. J Microbiol Immunol Infect 41: 4-8.

24. Ali M, Kanwal L, Tassaduqe K, Iqbal R (2009) Prevalence of Hepatitis C virus $(\mathrm{HCV})$ in relation to its promotive factors among the human urban population of Multan, Pakistan. Eur J Gen Med 6: 94-98.

25. Muhammad N, Jan MA (2005) Frequency of Hepatitis C in Buner, NWFP. J Coll Physicians Surg Pak 15:11-14.

26. Rauf MS, Nadeem A, Ali H, Riaz M, Iqbal M, et al. (2010) Prevalence of Hepatitis B and C in internally displaced persons of war against terrorism in Swat, Pakistan. Eur J Public Health 21: 638-642.

27. Idrees M, Riazuddin S (2008) Frequency distribution of Hepatitis $C$ virus genotypes in different geographical regions of Pakistan and their possible routes of transmission. BMC Infect Dis 8: 69.

28. Ijaz T, Khan MA, Jafri SA, Ranjha FA, Mehmood KA, et al. (2008) Prevalence of Hepatitis C Virus (HCV) genotype $3 \mathrm{a}$ in the infected population of Lahore, Pakistan. Int J Infect Dis 12: e421. 